\title{
Redescription of the Siamese shield leech Placobdelloides siamensis with new host species and geographic range
}

\author{
Krittiya Chiangkul, Poramad Trivalairat, and Watchariya Purivirojkul* \\ Animal Systematics and Ecology Speciality Research Unit, Department of Zoology, Faculty of Science, Kasetsart University, \\ 50 Ngam Wong Wan Road, Chatuchak, Bangkok 10900, Thailand
}

Received 13 April 2018, Accepted 31 October 2018, Published online 26 November 2018

\begin{abstract}
The Siamese shield leech Placobdelloides siamensis (Oka, 1917) Sawyer, 1986 (Euhirudinea: Glossiphoniidae) was collected from five new host species, Southeastern Asian Box Turtle (Cuora amboinensis), Yellow-headed Temple Turtle (Heosemys annandalii), Malayan Snail-eating Turtle (Malayemys macrocephala), Mekong Snail-eating Turtle (M. subtrijuga), and Khorat Snail-eating Turtle (M. khoratensis) and was found for the first time in Udon Thani, Thailand. Examination of live leeches provided, for the first time, data on coloration and the combination of parental care behavior, both carrying cocoons and attaching cocoons to the substrate. This species was separated from its congeners based on the following characters: one pair of eyes; spines at proboscis subterminal; mouth terminal on oral sucker; absent plaque in neck region; gonopores located in furrow and separated by two annuli; distinctly triannulated mid-body segments; crop with seven pairs and branched caeca; caudal sucker slightly over half of maximum body width; and strongly dorsal papillae. Phylogenetic relationships based on the COI and ND1 genes were clarified and demonstrated that the species is distinct from others. The original description was amended and the taxonomic history is discussed.
\end{abstract}

Key words: Placobdelloides, Glossiphoniidae, Hirudinea, Clitellata, Leech, Snail-eating turtle, Malayemys, Bangkok, Thailand.

\begin{abstract}
Résumé - Redescription de la sangsue Placobdelloides siamensis, avec nouvelles espèces d'hôtes et nouvelle aire de répartition géographique. La sangsue Placobdelloides siamensis (Oka, 1917) Sawyer, 1986 (Euhirudinea: Glossiphoniidae) a été collectée chez cinq nouvelles espèces d'hôtes, les tortues Cuora amboinensis, Heosemys annandalii, Malayemys macrocephala, M. subtrijuga et M. khoratensis, et a été trouvée pour la première fois à Udon Thani, en Thaïlande. L'examen des sangsues vivantes a fourni pour la première fois des données sur la coloration et la combinaison du comportement des parents en matière de protection parentale, qui à la fois portent des cocons et les fixent au substrat. Cette espèce a été séparée de ses congénères selon les caractères suivants : une paire d'yeux ; épines au proboscis subterminal ; bouche terminale sur la ventouse orale ; plaque absente dans la région du cou ; gonopores situés dans un sillon et séparés par deux anneaux; segments du milieu du corps distinctement triannulés ; jabot avec sept paires de caeca ramifiés ; ventouse caudale légèrement au-dessus de la moitié de la largeur maximale du corps; et papilles fortement dorsales. Les relations phylogénétiques basées sur les gènes COI et ND1 ont été clarifiées et ont démontré que l'espèce est distincte des autres. La description originale a été modifiée et l'histoire taxonomique est discutée.
\end{abstract}

\section{Introduction}

Placobdelloides Sawyer, 1986 [20] is a genus of glossiphoniid leeches, currently composed of 16 species found worldwide, i.e., in Africa (Placobdelloides fimbriata Johansson, 1909 [6]; P. jaegerskioeldi Johansson, 1909; P. multistriata Johansson, 1909 [13, 19]), Australia and the United States, eastward to India (P. fulva Harding, 1921 [17]; P. emydae

\footnotetext{
*Corresponding author: fsciwyp@ku.ac.th
}

Harding, 1924 [4, 10]; P. undulata Harding, 1924 [11]; P. horai Baugh, 1960 [2]; P. indica Baugh, 1960 [2]), and Southeast Asia (P. siamensis Oka, 1917 in China and Thailand [1]; P. okadai Oka, 1925 [18] in China; P. okai Soós, 1969 [22]; P. stellapapillosa Goverdich et al., 2002 [9] in Malaysia and Singapore), and throughout Australia and New Zealand (P. octostriata Grube, 1866 [24]; P. maorica Benham, 1907 [15]; P. bancrofti Best, 1931 [16]; P. bdellae Ingram, 1957 [12]). Lacking a jaw, they usually feed with a protrusible proboscis and are predacious or sanguivorous, or both, on a variety of prey living in nearby 
water systems, such as shrimps, waterfowl, fish, amphibians, turtles, crocodiles or mammals (P. octostriata Grube, 1866; P. maorica Benham, 1907; P. bancrofti Best, 1931; P. bdellae Ingram, 1947) [9, 17, 20, 21, 24].

In Thailand, turtles are commonly used in the practice of religious merit release and are believed to grant a long life to the releaser. Frequently found species of turtles include Southeast Asian Box Turtle (Cuora amboinensis Daudin, 1802), Yellow-headed Temple Turtle (Heosemys annandalii Boulenger, 1903), Black Marsh Turtle (Siebenrockiella crassicollis Gray, 1831) and Red-eared Slider Turtle Trachemys scripta elegans Wied-Neuwied, 1839 (alien species). Snaileating turtles are freshwater species belonging to the Malayemys genus, with three species members, Malayemys macrocephala Gray 1859, M. subtrijuga Schlegel and Müller 1845 and M. khoratensis Ihlow, Vamberger, Flecks, Hartmann, Cota, Makchai, Meewattana, Dawson, Kheng, Rödder and Fritz 2016, from Southeast Asia [3, 7, 23]. There have been almost no reports on their infection with leeches before; however, in this study, these turtles from various areas were found to be heavily infected with freshwater leeches, subsequently identified as Placobdelloides siamensis.

The Siamese shield leech $P$. siamensis was originally described in the early 20th century as Hemiclepsis siamensis Oka, 1917 from the black marsh turtle Bellie crassicollis Gray, 1831 (currently, S. crassicollis), which originated from Lampam, Patalung, Thailand, before having been reclassified to the current name by Sawyer in 1986 [1, 5, 20]. Even though Siddall et al. [21] have previously sequenced and reported this species from Wat Bovorn, Bangkok, Thailand, they did not describe the host species, nor did they update the data. Therefore, in this study, we examined information on P. siamensis to expand the original description by updating the known morphology and host range in Thailand, and including the ban on the release of turtles to prevent the spread of P. siamensis.

\section{Materials and methods}

\section{Leech preparation}

Snail-eating turtles (Malayemys macrocephala $=18$; M. Subtrijuga $=12$ ) and Heosemys annandalii were collected from ponds at Kasetsart University, Bangkok Province, Thailand $\left(13^{\circ} 50^{\prime} 53.6^{\prime \prime} \mathrm{N}, 100^{\circ} 33^{\prime} 47.3^{\prime \prime} \mathrm{E}\right)$ from February to July 2017. Turtles were collected by hand at night. Some leeches were removed using forceps and then stored in $70 \%$ ethanol for identification, while others were stored in absolute ethanol.

\section{Morphological study}

Approximately 3852 individual leeches were collected, from 20 host specimens, 9 M. khoratensis from Montri Sumontha (Udon Thani District, Udon Thani Province, $17^{\circ} 36^{\prime} 55.5^{\prime \prime} \mathrm{N}$, $\left.102^{\circ} 81^{\prime} 42.7^{\prime \prime} \mathrm{E}\right)$ and 11 Cuora amboinensis from the Phraya Suren Temple market, Bangkok Province (13 $52^{\prime} 23.6^{\prime \prime} \mathrm{N}$, $\left.100^{\circ} 42^{\prime} 03.6^{\prime \prime} \mathrm{E}\right)$. For morphological characterization, leeches were examined for eye number and placement, annulation, digestive system (including the number and structure of gastric ceca), and reproductive system under a DVM6 digital microscope (Leica Microsystems (SEA) Pte. Ltd.) at a $2350 \times$ magnification. For scanning electron microscopy (SEM), leeches were preserved in absolute alcohol, then dried using the critical point dry (CPD) technique, coated in gold, and examined under a microscope.

\section{Molecular analysis}

Leeches were cut into two pieces equally; the anterior part was kept in an absolute ethanol. Posterior part was used for DNA isolation with the DP304-02 TIANamp Genomic DNS, following the protocol given for the purification of total DNA from animal tissue (spin column). For the proteinase $\mathrm{K}$ treatment step, tissue samples were lysed for several hours at $56^{\circ} \mathrm{C}$. DNA was eluted from the spin column with $150 \mu \mathrm{L}$ of buffer.

Polymerase chain reactions (PCRs) were prepared using EP0402 TAQ DNA Polymerase. Primers were ordered from Integrated DNA Technologies and were comprised of two primers each for cytochrome $c$ oxidase subunit I (CO-I) and nicotinamide adenine dinucleotide dehydrogenase subunit I (ND-1), as specified by Light and Siddall (1999) [14]. Specifically, the CO-I primers were LCO1490 (5'-GGT CAA CAA ATC ATA AAG ATA TTG G-3') and HCO2198 (5'-TAA ACT TCA GGG TGA CCA AAA AAT CA- $3^{\prime}$ ). The ND-I primers were LND300 (5'-TGG CAG AGT AGT GCA TTA GG-3') and HND1932 (5'-CCT CAG CAA AAT CAA ATG G-3'). Final volume of PCR reactions was $30 \mathrm{~mL}$ with $3 \mathrm{~mL}$ of leech genomic DNA added per reaction. DNA was amplified under the following PCR conditions: $94{ }^{\circ} \mathrm{C}$ for $5 \mathrm{~min} ; 35$ cycles of $94{ }^{\circ} \mathrm{C}$ for $30 \mathrm{~s}, 50{ }^{\circ} \mathrm{C}$ for $30 \mathrm{~s}, 72^{\circ} \mathrm{C}$ for $45 \mathrm{~s} ; 72{ }^{\circ} \mathrm{C}$ for $7 \mathrm{~min}$.

\section{Statistical analysis}

PCR products were purified and sequenced using either the HCO2198 and LCO1490 primers for the CO-I products or the HND1932 and LND300 for the ND-I products by Macrogen Korea. The sequences obtained were submitted to GenBank (Table 1). Comparative sequences were retrieved from GenBank. The DNA sequences were aligned using ClustalW version 1.83 software and analyzed using MEGA6 version 6 software for Maximum likelihood analyses, and MrBayes version 3.1.2 software for Bayesian analysis.

Maximum likelihood analyses consisted of 2000 replicates of tree search with 25 initial GAMMA rate categories and final optimization using four GAMMA shape categories; bootstrap values were calculated using 2000 pseudoreplicates of the rapid bootstrap algorithm. And Bayesian analysis was run for 2 million generations with tree sampled every 100 generations, with the general time reversible (GTR) model and GAMMA distribution of nucleotide rates for all partitions. Burn-in was set to $10 \%$.

\section{Results \\ Description}

Specimens were determined to belong to Placobdelloides 1986 and were characterized as triannulate in the mid-body, with one pair of eyes on somite III, a terminal mouth pore, a crop with seven pairs of gastric ceca, a gonopore between 
Table 1. GenBank accession numbers for leech sequences used in the phylogenetic analysis of Placobdelloides.

\begin{tabular}{|c|c|c|}
\hline \multirow[t]{2}{*}{ Taxon } & \multicolumn{2}{|c|}{ GenBank accession numbers } \\
\hline & $\mathrm{COI}$ & ND1 \\
\hline \multicolumn{3}{|l|}{ Ingroup } \\
\hline AN000016CE & МH777419 & MH777409 \\
\hline AN000017CE & MH777420 & MH777413 \\
\hline AN000018CE & MH777418 & MH777411 \\
\hline AN000021CE & MH777415 & MH777412 \\
\hline AN000022CE & MH777417 & MH777410 \\
\hline AN000023CE & MH777416 & MH777414 \\
\hline Placobdelloides jaegerskioeldi & AY962463 & AY962450 \\
\hline Placobdelloides multistriata & DQ414338 & DQ414383 \\
\hline Placobdelloides siamensis & AY962449 & AY962462 \\
\hline \multicolumn{3}{|l|}{ Outgroup } \\
\hline Alboglossiphonia heteroclite & AF116016 & AY047339 \\
\hline Alboglossiphonia quadrata & AY962455 & AY962441 \\
\hline Alboglossiphonia weberi & AY962453 & AY962440 \\
\hline Batracobdelloides tricarinata & AY962457 & AY962445 \\
\hline Glossiphonia baicalensis & AY047329 & AY047355 \\
\hline Glossiphonia complanate & MF458715 & AY047345 \\
\hline Glossiphonia concolor & AY962458 & AY962446 \\
\hline Glossiphonia elegans & AY047322 & AY047335 \\
\hline Glossiphonia verrucata & AY962459 & AY962447 \\
\hline Helobdella fusca & AF329038 & AF329061 \\
\hline Helobdella robusta & MF067148 & MF067201 \\
\hline Hemiclepsis marginata & AF003259 & AY047336 \\
\hline Hirudo medicinalis & HQ333517 & KU672396 \\
\hline Marsupiobdella africana & AF116015 & AY047347 \\
\hline Placobdella montifera & MF067129 & MF067212 \\
\hline Placobdella pediculate & MF067121 & MF067222 \\
\hline Theromyzon bifarium & AY047330 & AY047356 \\
\hline Theromyzon tessulatum & AY047318 & AY047338 \\
\hline
\end{tabular}

two annuli, a caudal sucker slightly over the half body width, and cocoons and eggs attached directly to both the ventral surface of an adult and to the substrate [1, 8, 20].

\section{Placobdelloides siamensis (Oka, 1917) Sawyer, 1986}

Syns. Hemiclepsis siamensis Oka, 1917; Placobdelloides siamensis (Oka, 1917) Sawyer, 1986.

\section{Taxonomic summary}

Type host: Black Marsh Turtle, Siebenrockiella crassicollis (Gray, 1831) Mertens et al., 1934

Additional hosts: Southeast Asian Box Turtle (Cuora amboinensis, Daudin, 1802); Yellow-headed Temple Turtle (Heosemys annandalii, Boulenger, 1903); Mekong Snail-eating Turtle (Malayemys subtrijuga, Schlegel and Müller, 1845, Lindholm, 1931); Malayan Snail-eating Turtle (M. Macrocephala, Gray, 1859, Brophy, 2004); Khorat Snail-eating Turtle (M. Khoratensis, Ihlow, Vamberger, Flecks, Hartmann, Cota, Makchai, Meewattana, Dawson, Kheng, Rödder and Fritz 2016) (this study).

Additional locality: Kasetsart University, Bangkok Province $\left(13^{\circ} 50^{\prime} 53.6^{\prime \prime} \mathrm{N}, 100^{\circ} 33^{\prime} 47.3^{\prime \prime}\right.$ E), Phraya Suren Temple market, Bangkok Province (1352'23.6" N, 100 $\left.42^{\prime} 03.6^{\prime \prime} \mathrm{E}\right)$, Udon Thani District, Udon Thani Province $\left(17^{\circ} 36^{\prime} 55.5^{\prime \prime} \mathrm{N}\right.$, $\left.102^{\circ} 81^{\prime} 42.7^{\prime \prime} \mathrm{E}\right)$

Site of infection: external surfaces (carapace, head, neck, axilla, groin and tail), including inside mouth (Fig. 5)

Type locality: Lampam District, Patalung Province, Thailand.

Specimen deposited: Zoological Museum Kasetsart University (ZMKU), Department of Zoology, Faculty of Science, Kasetsart University, Bangkok, Thailand, ZMKUANN-0001-5.

\section{External morphology}

Body of mature $P$. siamensis an elongated oval, $25 \mathrm{~mm}$ in length, maximum head and body width 2.35 and $5.57 \mathrm{~mm}$, respectively (Fig. 1). Entire dorsal surface rough, with numerous well-developed 5-9 longitudinal rod papillae present. No regular arrangement pattern, except a row of papillae on each side of the median line. Ventral surface entirely smooth.

Oral sucker small (average $1.86 \mathrm{~mm}$ diameter), with mouth opening at terminal portion and numerous pits inside (Fig. 2A). One pair of eyes, located on dorsal surface of somite III (Fig. 2B). Eyes touch. Male genital pore situated in furrow between annuli 22 ( $3 \mathrm{rd}$ ring of somite $\mathrm{X}$ ) and 23 (1st ring of somite XI) (Fig. 3). Female pore lies in furrow of somite XI between annuli 24 (1st ring) and 25 (2nd ring). Two annuli separate the gonopores, and anus separates last annulus and caudal sucker. Caudal sucker over half of body width (average $3.00 \mathrm{~mm}$ in diameter), no pits.

\section{Internal anatomy}

Blunt elongated cylindrical proboscis from terminal lip of oral sucker to posterior proboscis sheath, followed by elongated esophagus, to which discrete compact bunch of salivary glands and diverticulate esophagus glands open. Seven pairs of diverticulated crop ceca, with last pair extending posteriorly and diverticulated into four sections. Four pairs of simple saccular intestinal, with last pair extending posteriorly to simple rectum and anus. Anus opens on dorsal surface behind the last annulus (Fig. 4).

Male genital pore opens to glasses shaped sac, posteriorly to the diverticulate esophagus, and diverts to vas deferens on each side. Vas deferens posterior, opens to six pairs of curly rounded testes, each located close to the distal edge of each crop branch. Female pore situated posteriorly to male genital pore, opens to a sac which continues into elongated ovary on each side. Typically, ovaries coiled anteriorly the first crop caeca; however, after mating and egg producing, ovaries are elongated posteriorly from numerous eggs inside them.

\section{Molecular analysis}

The Bayesian trees of the COI-ND1 genes of the Glossiphoniid leeches had high probability support values for the monophyly of AN000016CE, AN000017CE, AN000018CE, AN000021CE, AN000022CE, AN000023CE, P. siamensis, and P. Jaegerskioeldi, but also revealed non-monophyly of 


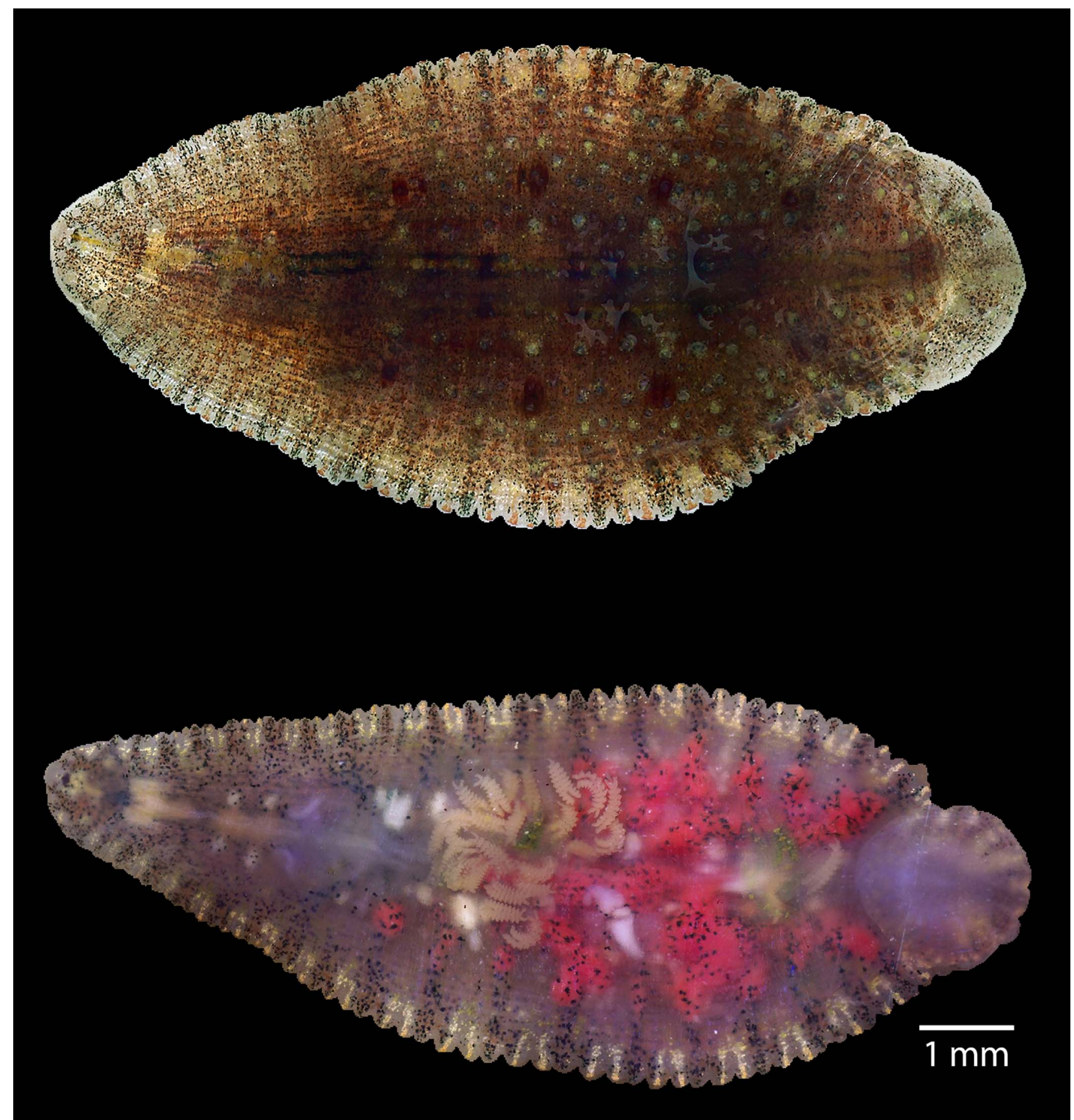

Figure 1. Dorsal surface (upper) and ventral surface (lower) of Placobdelloides siamensis. Ventral surface showing numerous young leeches.

P. multistriatus (Fig. 6). The maximum-likelihood trees also yielded monophyletic groups, similar to the Bayesian trees, but the data were different for P. jaegerskioeldi and P. multistriatus. The barcoding results also confirmed that AN000016CE, AN000017CE, AN000018CE, AN000021CE, AN000022CE, and AN000023CE were P. siamensis.

\section{Discussion}

This is the first record of $P$. siamensis from C. amboinensis, $H$. annandalii, M. macrocephala, M. subtrijuga, and M. khoratensis. This leech has currently been recorded from six species of turtles from the same family (Geoemydidae). 
a

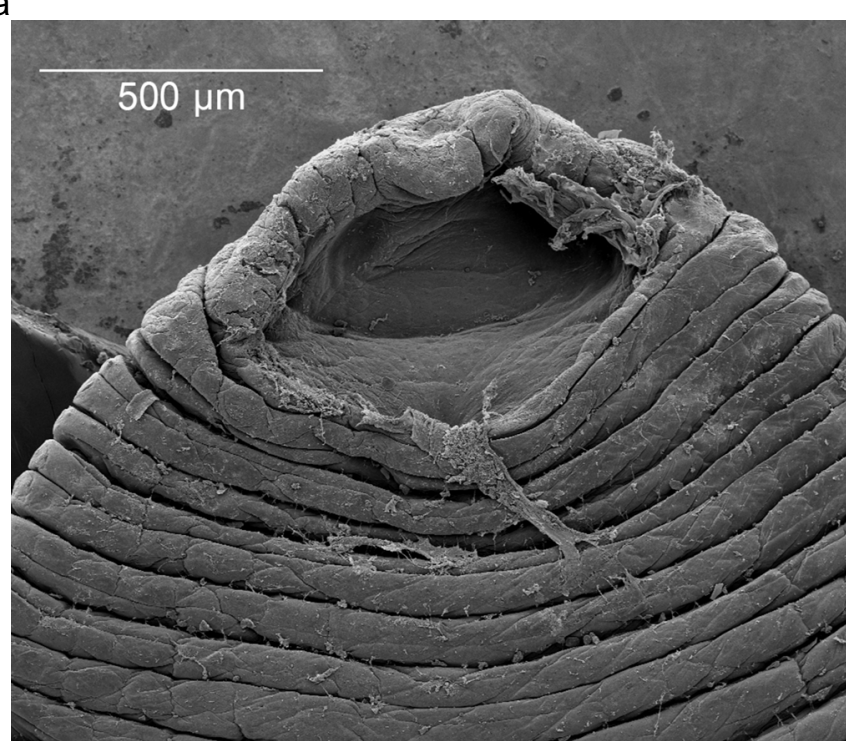

b

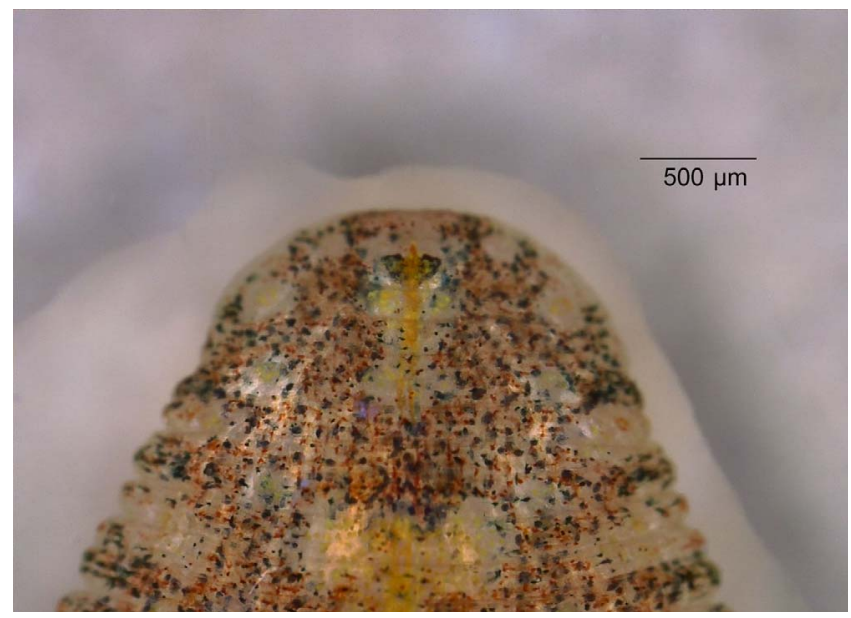

Figure 2. Anterior part of Placobdelloides siamensis. (A) Scanning electron microscope (SEM) showing oral sucker, numerous pits inside and mouth at terminal lip, (B) Dorsal surface showing eye placement at somite III. The dorsal color is uniformly brownishgray, with randomly distributed dark brown, yellow, and green spots. The dorsal median line is yellowish, between four pairs of scarlet ovals. On the margin, brown, yellow, and green spots are present along the caudal sucker. The ventral surface is transparent.

In addition, this is the first record of P. siamensis from Udon Thani (northeastern province) in Thailand. The leech was previously reported only in Patalung (southern province) and Bangkok (central province) in Thailand, as well as in Nanking, China [20, 21]. Even though this leech has been shown to feed on numerous Geoemydidae turtles, as mentioned above, there have been no records that it is able to feed on other families, as found in this study. Moreover, it tends to spread throughout Thailand following its host distributions.

The morphological characters that separated this P. siamensis from it congeners are one pair of eyes; spines at the proboscis subterminal; mouth terminal on oral sucker; absent plaque in neck region; gonopores located in furrow

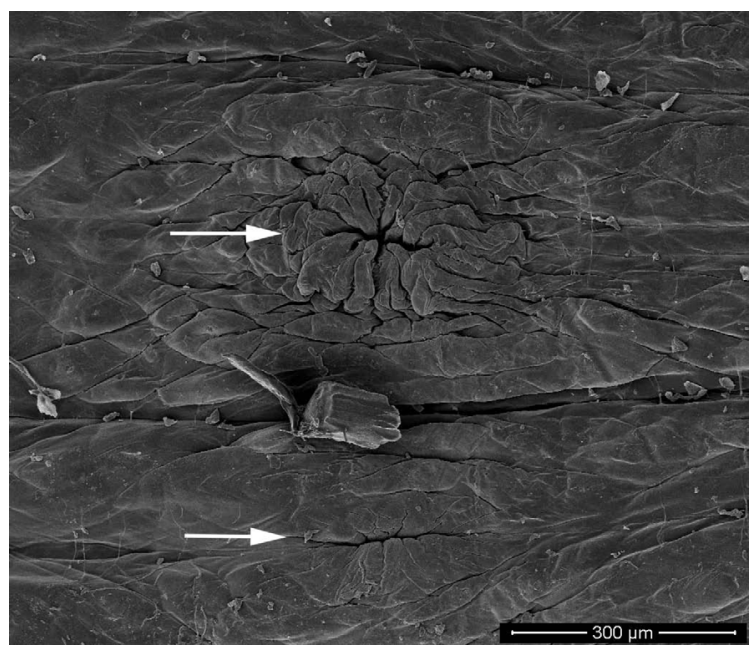

Figure 3. Scanning electron micrograph of the ventral surface of Placobdelloides siamensis showing the arrangement of gonopores. Upper image is the male gonopore and lower is female.

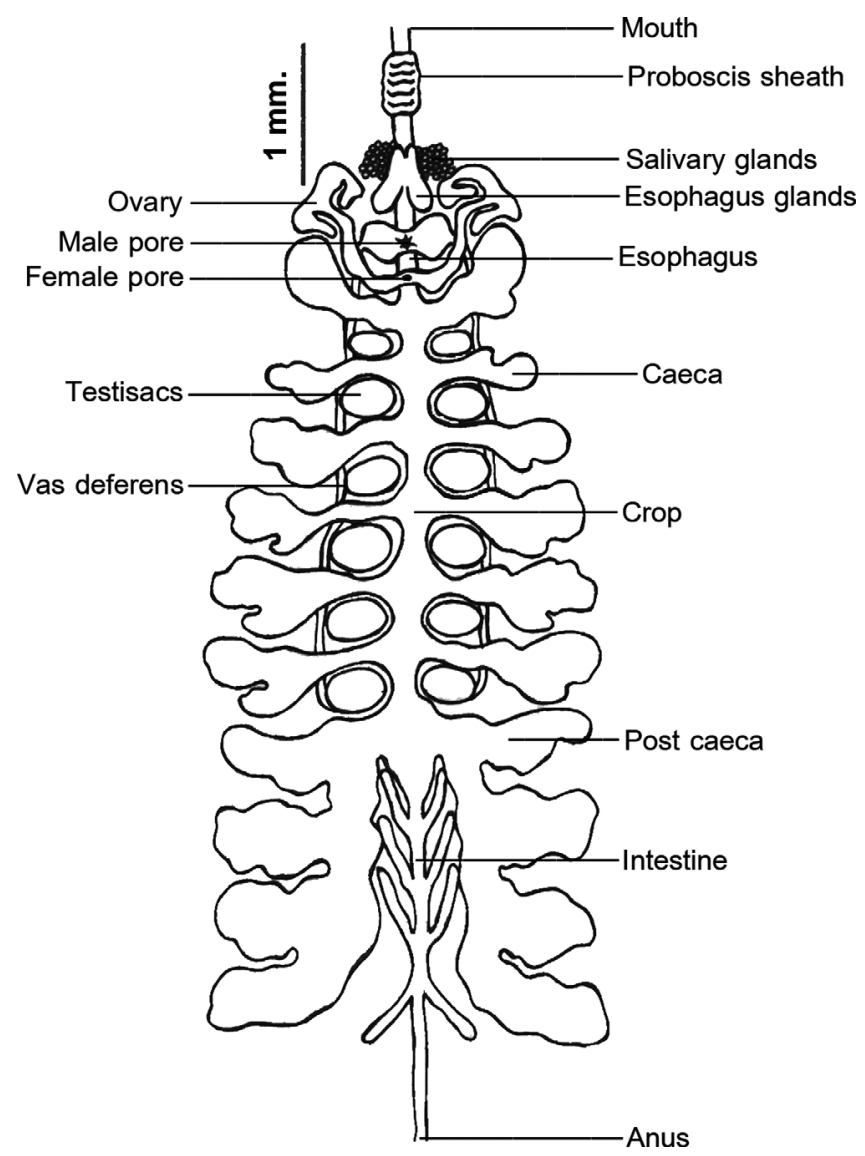

Figure 4. Internal anatomy of Placobdelloides siamensis.

and separated by two annuli; distinctly triannulated mid-body segments; crop with seven pairs and branched ceca; caudal sucker slightly over half maximum body width; and strongly dorsal papillae. The specimens collected in this study almost 

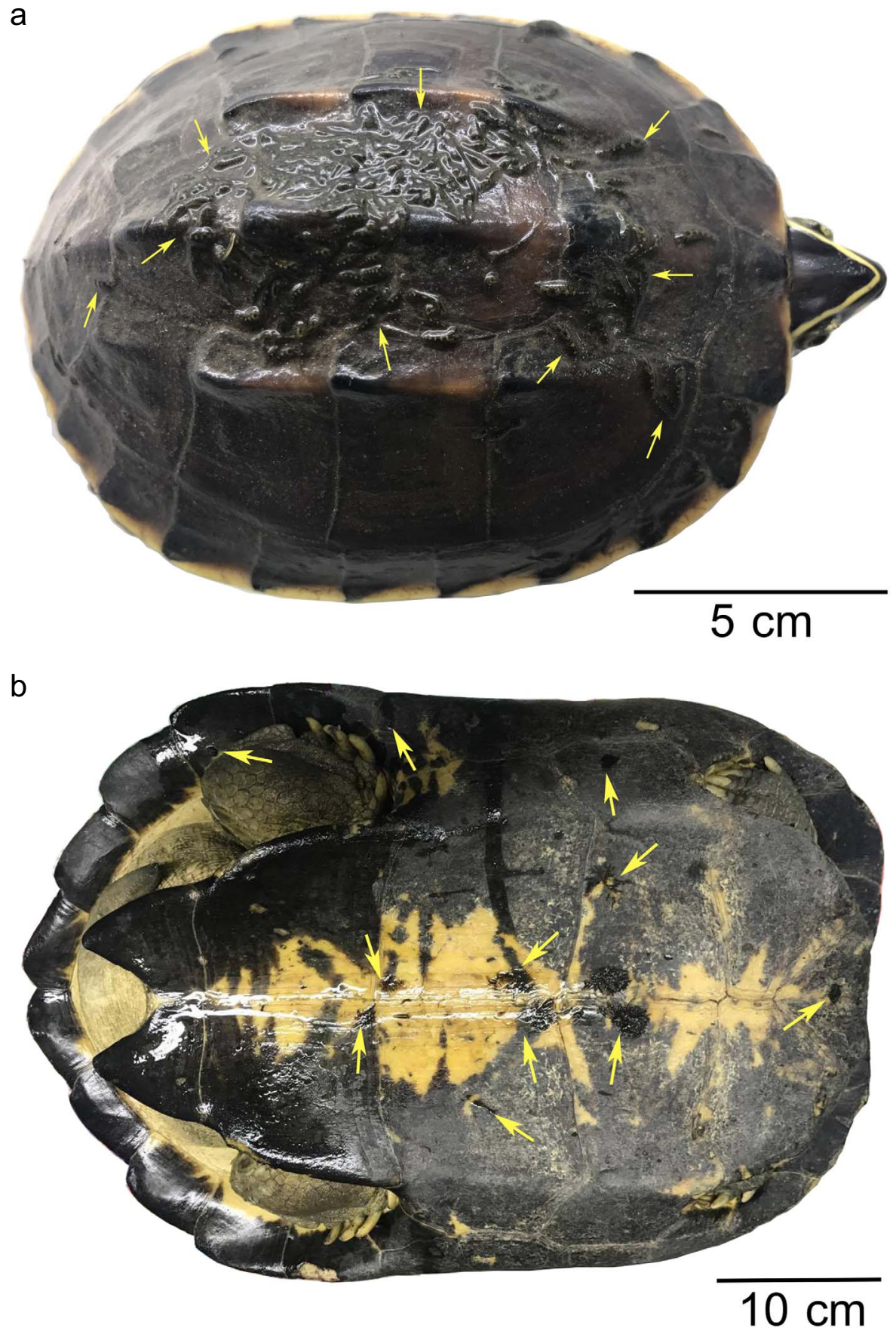

Figure 5. Parasitism of Placobdelloides siamensis on (A) the carapace of Malayemys subtrijuga and (B) plastron of Heosemys annandalii.

matched the description of $P$. siamensis (in alcohol) by Annandale [1], except the male and female gonopores. The male gonopore had been described as situated between annuli 25 and 26 (somite XI and XII), while it was situated between annuli 22 and 23 (somite X and XI) in this study.

The female gonopore had been described as situated between annuli 27 and 28 (somite XII), while it was situated between annuli 24 and 25 (somite XI) in this study. Since
Annandale [1] used preserved specimens, no information on coloration in life was provided. The report by Siddall et al. [21] on the sequencing of $P$. siamensis from Wat Bovorn did not describe morphological details, nor the host. Collection of a large number of live leeches in this study allowed us to describe the external coloration and morphology.

All specimens examined were mature, with developed testisacs and ovisacs present. Some specimens carried cocoons 
a

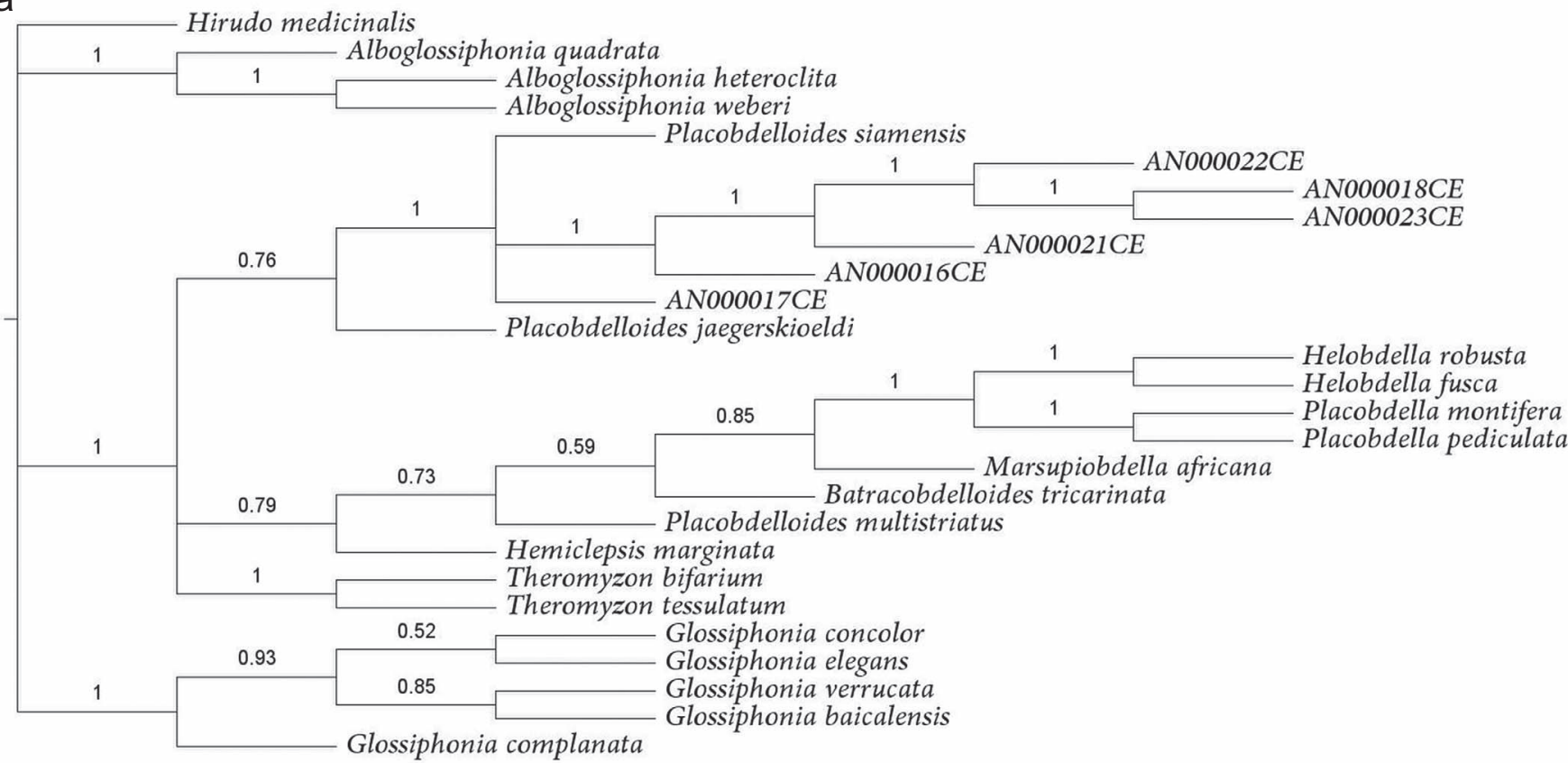

b

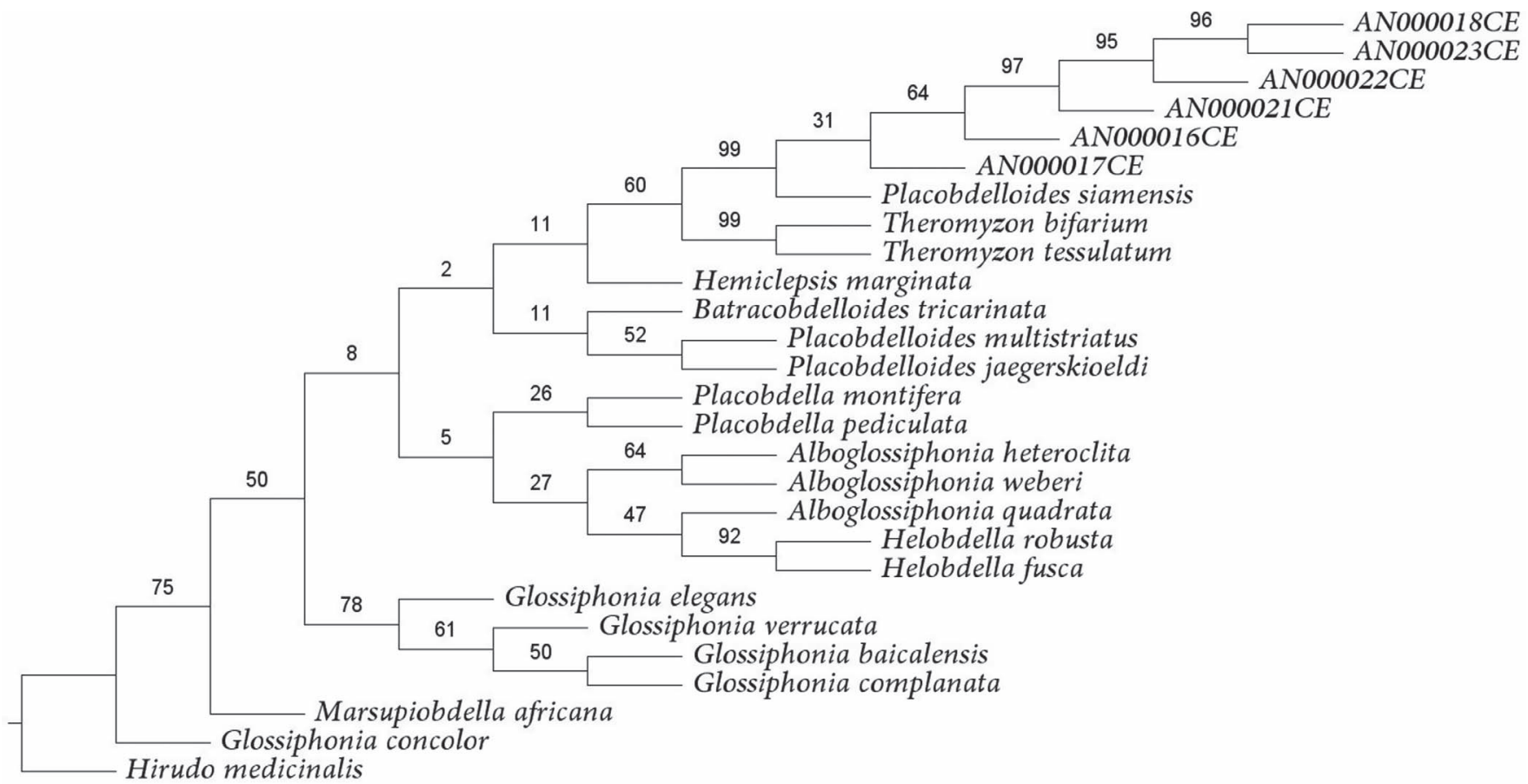

Figure 6. Phylogeny analysis of the COI-ND1 gene of glossiphoniid leeches (Table 2): the upper diagram is the Bayesian analysis; lower is the maximum likelihood analysis. 
Table 2. Pairwise $p$-distance values of the COI-ND1 gene within and among 20 species of the Glossiphoniidae family, Hirudo medicinalis and the sequences (AN000016CE, AN000017CE, AN000018CE, AN000021CE, AN000022CE and AN000023CE) identified in this study.

\begin{tabular}{|c|c|c|c|c|c|c|c|c|c|c|c|c|c|c|c|c|c|c|c|c|c|}
\hline & 1 & 2 & 3 & 4 & 5 & 6 & 7 & 8 & 9 & 10 & 11 & 12 & 13 & 14 & 15 & 16 & 17 & 18 & 19 & 20 & 21 \\
\hline \multicolumn{22}{|l|}{ Hirudo medicinalis } \\
\hline Glossiphonia concolor & 0.802 & & & & & & & & & & & & & & & & & & & & \\
\hline Alboglossiphonia quadrata & 0.536 & 0.457 & & & & & & & & & & & & & & & & & & & \\
\hline Alboglossiphonia heteroclite & 0.569 & 0.538 & 0.288 & & & & & & & & & & & & & & & & & & \\
\hline Alboglossiphonia weberi & 0.518 & 0.428 & 0.205 & 0.193 & & & & & & & & & & & & & & & & & \\
\hline Helobdella robusta & 0.615 & 0.498 & 0.270 & 0.325 & 0.260 & & & & & & & & & & & & & & & & \\
\hline Helobdella fusca & 0.599 & 0.525 & 0.252 & 0.330 & 0.254 & 0.185 & & & & & & & & & & & & & & & \\
\hline Placobdelloides siamensis & 0.514 & 0.435 & 0.249 & 0.294 & 0.217 & 0.253 & 0.269 & & & & & & & & & & & & & & \\
\hline These studied sequences & $0.512-$ & $0.431-$ & $0.245-$ & 0.294 & $0.218-$ & 0.250 & 0.269 & $0.007-$ & $0.002-$ & & & & & & & & & & & & \\
\hline & 0.561 & 0.457 & 0.288 & 0.347 & 0.262 & 0.295 & 0.310 & 0.075 & 0.081 & & & & & & & & & & & & \\
\hline Placobdella montifera & 0.554 & 0.473 & 0.263 & 0.336 & 0.257 & 0.218 & 0.239 & 0.215 & $\begin{array}{l}0.217- \\
0.260\end{array}$ & & & & & & & & & & & & \\
\hline Placobdella pediculate & 0.531 & 0.482 & 0.257 & 0.317 & 0.233 & 0.259 & 0.260 & 0.222 & $\begin{array}{l}0.224- \\
0.260\end{array}$ & 0.198 & & & & & & & & & & & \\
\hline Glossiphonia elegans & 0.507 & 0.340 & 0.222 & 0.262 & 0.175 & 0.259 & 0.276 & 0.202 & $\begin{array}{l}0.202- \\
0.247\end{array}$ & 0.235 & 0.220 & & & & & & & & & & \\
\hline Glossiphonia verrucata & 0.538 & 0.336 & 0.226 & 0.302 & 0.197 & 0.276 & 0.297 & 0.220 & $\begin{array}{l}0.218- \\
0.257\end{array}$ & 0.256 & 0.253 & 0.123 & & & & & & & & & \\
\hline Glossiphonia baicalensis & 0.509 & 0.327 & 0.211 & 0.272 & 0.185 & 0.256 & 0.269 & 0.205 & $\begin{array}{l}0.201- \\
0.249\end{array}$ & 0.224 & 0.231 & 0.108 & 0.091 & & & & & & & & \\
\hline Glossiphonia complanate & 0.494 & 0.339 & 0.217 & 0.273 & 0.179 & 0.257 & 0.272 & 0.189 & $\begin{array}{l}0.189 \\
0.229\end{array}$ & 0.232 & 0.220 & 0.101 & 0.107 & 0.091 & & & & & & & \\
\hline Marsupiobdella africana & 0.522 & 0.466 & 0.262 & 0.294 & 0.229 & 0.245 & 0.262 & 0.191 & $\begin{array}{l}0.193- \\
0.243\end{array}$ & 0.226 & 0.229 & 0.214 & 0.242 & 0.222 & 0.220 & & & & & & \\
\hline Batracobdelloides tricarinata & 0.554 & 0.452 & 0.257 & 0.317 & 0.229 & 0.260 & 0.240 & 0.202 & $\begin{array}{l}0.203- \\
0.238\end{array}$ & 0.215 & 0.236 & 0.217 & 0.225 & 0.218 & 0.195 & 0.206 & & & & & \\
\hline Hemiclepsis marginata & 0.520 & 0.455 & 0.224 & 0.317 & 0.225 & 0.272 & 0.256 & 0.194 & $\begin{array}{l}0.193- \\
0.238\end{array}$ & 0.222 & 0.226 & 0.214 & 0.221 & 0.199 & 0.210 & 0.218 & 0.199 & & & & \\
\hline Placobdelloides multistriatus & 0.500 & 0.431 & 0.214 & 0.275 & 0.187 & 0.232 & 0.225 & 0.171 & $\begin{array}{l}0.171- \\
0.218\end{array}$ & 0.190 & 0.189 & 0.199 & 0.197 & 0.177 & 0.175 & 0.177 & 0.170 & 0.181 & & & \\
\hline Placobdelloides jaegerskioeldi & 0.507 & 0.424 & 0.235 & 0.291 & 0.198 & 0.254 & 0.263 & 0.166 & $\begin{array}{l}0.165- \\
0.205\end{array}$ & 0.202 & 0.210 & 0.191 & 0.190 & 0.186 & 0.182 & 0.197 & 0.194 & 0.181 & 0.142 & & \\
\hline Theromyzon bifarium & 0.518 & 0.414 & 0.210 & 0.292 & 0.191 & 0.239 & 0.245 & 0.158 & $\begin{array}{l}0.156- \\
0.199\end{array}$ & 0.191 & 0.191 & 0.178 & 0.179 & 0.179 & 0.166 & 0.186 & 0.185 & 0.162 & 0.144 & 0.152 & \\
\hline Theromyzon tessulatum & 0.522 & 0.419 & 0.214 & 0.294 & 0.194 & 0.242 & 0.249 & 0.160 & $\begin{array}{l}0.160- \\
0.201\end{array}$ & 0.194 & 0.193 & 0.179 & 0.183 & 0.181 & 0.169 & 0.189 & 0.186 & 0.166 & 0.144 & 0.155 & 0.003 \\
\hline
\end{tabular}


or young on the posterior ventral surface, as in the original description. In this study, some cocoons were attached to the substrate. The number of eggs was documented to be between 173 and 412 per individual in 14 specimens.

In the original description, Annandale [1] hesitated to classify this species into Hemiclepsis or Placobdella because of the oval shape, one pair of eyes, a pattern of numerous irregular papillae, gonopores separated by two annuli, and cocoons carried on the ventral side. Finally, it was placed in Hemiclepsis based on the distinctly posterior position of the mouth, although Hemiclepsis is characterized by 9-11 pairs of crop ceca, 2-3 pairs of eyes, gonopores separated by two annuli, and the attachment of cocoons to the substrate [20].

Sawyer [20] subsequently moved $H$. siamensis to P. siamensis because of the following similarities: one pair of eyes, an esophageal organ, seven pairs of crop ceca, a terminal mouth pore, gonopores separated by two annuli, and a combination of the parental care behavior, either carrying cocoons on the ventral surface or attached to the substrate.

Although Annandale [1] and Sawyer [20] clearly described the morphology of $P$. siamensis, this study provides a more complete overview of the morphological structure, coloration pattern, and parental care behaviors of $P$. siamensis, thus leading to a better understanding of its actual phylogenetic position within glossiphoniid leeches.

Acknowledgements. This research was supported by the graduate scholarship program of the graduate school, Kasetsart University, Center of Excellence on Biodiversity (BDC), Office of Higher Education Commission (Project Code BDC-PG2-161004) and Department of Zoology, Faculty of Science, Kasetsart University. We would like to thank Mr. Montri Sumontha for some leech specimens and Asst. Prof. Dr. Pradit Saengthong for his kindness, assistance, and guidance. We also thank the reviewers and editors for their help.

\section{References}

1. Annandale N. 1925. Zoological result of a tour in the Far East. The Journal of the Asiatic Society of Bengal, 9, 167-169.

2. Baugh SC. 1960. Studies on Indian Rhynchobdellid leeches-II. Zoologischer Anzeiger, 165, 468-477.

3. Brophy TR. 2004. Geographic variation and systematics in the South-East Asian turtles of the genus Malayemys (Testudines: Bataguridae). Hamadryad, 29(1), 63-79.

4. Chandra M. 1977. A check-list of leeches of Himachal Pradesh, India. Records of the Zoological Survey of India, 73, 189-195.

5. China Science and Technology Press. 2015. Siamese shield leech. Life science. Available Source: http://www.lifescience. com.cn/info/79773, January 20, 2018.

6. Cott HB. 1961. Scientific results of an inquiry into the ecology and economic status of the Nile crocodile (Crocodylus niloticus) in Uganda and northern Rhodesia. The Transactions of the Zoological Society of London Banner, 29, 211-337.
7. Das I. 2010. A field guide to the reptile of Thailand \& SouthEast Asia. New Holland: London.

8. Govedich ER. 2001. A reference guide to the ecology and taxonomy of freshwater and terrestrial leeches (Euhirudinea) of Australasia and Oceania. Cooperative research centre for freshwater ecology identification guide no. 35. Thurgoona: New South Wales, Australia.

9. Govedich FR, Bain BA, Davies RW. 2002. Placobdelloides stellapapillosa sp. n. (Glossiphoniidae) found feeding on crocodiles and turtles. Hydrobiologia, 474, 253-256.

10. Harding WA. 1920. Fauna of the Chika Lake: Hirudinea. Memoirs of the Indian Museum, 5(7), 509-518.

11. Harding WA. 1924. Description of some new leeches from India, Bunna and Ceylon. The Annals and Magazine of Natural History, 14(9), 489.

12. Ingram DM. 1957. Some Tasmanian Hirudinea. Papers and Proceedings of the Royal Society of Tasmania, 91, 191-232.

13. Johansson L. 1909. Einige neue Arten Glossosiphoniden aus dem Sudan. Zoologischer Anzeiger, 165, 468-477.

14. Light JE, Siddall ME. 1999. Phylogeny of the leech family Glossiphoniidae based on mitochondrial gene sequence and morphological data. Parasitology, 85, 815-823.

15. Mason J. 1974. Studies on the freshwater and terrestrial leeches of New Zealand - 1 Family Glossiphoniidae Vaillant. Journal of the Royal Society of New Zealand, 4(3), 327-343.

16. McKenna SA, Betts DA, Pong WW, Govedich FR, Barton DP. 2005. A redescription of the Australian Leech Placobdelloides bancrofti with new records of its distribution. The Journal of Parasitology, 91(1), 117-121.

17. Nesemann H, Sharma G, Sinha RK. 2004. Aquatic annelida (Polychaeta, Oligochaeta, Hirudinea) of the Ganga River and adjacent water bodies in Patna (India: Bihar), with description of a new leech species (Family Salifidae). Naturhistorisches Museum Wien, 105, 139-187.

18. Oka A. 1925. Notices sur les Hirudine Hirudineés d'Extreme Orient. Annotationes Zoologicae Japonenses, 10, 311-335.

19. Oosthuizen JH. 1979. Redescription of Placobdella multistriata (Johansson, 1909) (Hirudinea: Glossiphoniidae). Koedoe, 22, 61-79.

20. Sawyer RT. 1986. Leech biology and behaviour. Vol. II: Feeding biology, ecology and systematics. Oxford University Press, Oxford, United Kingdom.

21. Siddall ME, Budinoff RB, Borda E. 2005. Phylogenetic evaluation of systematics and biogeography of the leech family Glossiphoniidae. Invertebrate Systematics, 19, 105-112.

22. Soós Ă. 1969. Identification key to the leech (Hirudinoidea) genera of the world, with a catalogue of the species. VI Family: Glossiphoniidae. Acta Zoologica Academiae Scientiarum Hungaricae, 15, 397-454.

23. Sumontha M, Brophy TR, Kunya K, Wiboonatthapol S, Pauwels OSG. 2016. A new snail-eating turtle of the genus Malayemys Lindholm, 1931 (Geoemydidae) from Thailand and Laos. Taprobanica, 8(1), 1-9.

24. Tucker AD, Fitzsimmons NN, Goverdich FR. 2005. Euhirudinea from Australian turtles (Chelodina burrungandjii and Emydura australis) of the Kimberley Plateau, Western Australia, Australia. Comparative Parasitology, 72(2), 241-244.

Cite this article as: Chiangkul K, Trivalairat P \& Purivirojkul W. 2018. Redescription of the Siamese shield leech Placobdelloides siamensis with new host species and geographic range. Parasite 25, 56. 
Reviews, articles and short notes may be submitted. Fields include, but are not limited to: general, medical and veterinary parasitology; morphology, including ultrastructure; parasite systematics, including entomology, acarology, helminthology and protistology, and molecular analyses; molecular biology and biochemistry; immunology of parasitic diseases; host-parasite relationships; ecology and life history of parasites; epidemiology; therapeutics; new diagnostic tools.

All papers in Parasite are published in English. Manuscripts should have a broad interest and must not have been published or submitted elsewhere. No limit is imposed on the length of manuscripts.

Parasite (open-access) continues Parasite (print and online editions, 1994-2012) and Annales de Parasitologie Humaine et Comparée (1923-1993) and is the official journal of the Sociéte Française de Parasitologie. 